\title{
The Causality between Indonesian Sharia Stock Index and Market Capitalization: Evidence from Indonesia
}

\author{
Fera Widyanata, Abdul Bashir* \\ Department of Development Economics, Faculty of Economics \\ Universitas Sriwijaya, Indonesia \\ *Email: abd.bashir@unsri.ac.id
}

Received: October, 2019; Accepted: March, 2020; Published: April, 2020 Permalink/DOI: http://dx.doi.org/10.17977/um002v12i12020p045

\begin{abstract}
This study investigates the relationship between the sharia stock index and market capitalization in Indonesia for the period 2011-2019. This study uses secondary data, it is monthly time series data with 97 months observation period from May 2011 until March 2019. The analysis technique of this study is the granger causality test that is complemented by the impulse response and variance decomposition test. the findings of the study indicated that there was only a one-way causality relationship between the Indonesian sharia stock index variable and market capitalization, which only the changes of market capitalization in the past affected the changes of the sharia stock trading value in the present but not vice versa. The effect of market capitalization changes will be responded strongly by sharia stock in the second and third month, and then return to a new stable condition. Furthermore, the changes in the value of market capitalization provide a sizable and continuous contribution to the changes of Indonesia sharia stock trading value.
\end{abstract}

Keywords: Sharia stock index; market capitalization; causality test JEL Classification: E22; E44; N20

\section{INTRODUCTION}

Islamic-based financial institutions and non-bank financial institutions are increasingly developing in Indonesia. The development of Islamic financial institutions began to grow significantly since 1998 after the economic crisis that struck almost the entire world. This is due to the fact in the field shows that the sharia-based economy and finance are able to withstand the shocks of the economic crisis (Al-smadi, Almsafir, \& Mukthar, 2017). Sharia-based finance also has its own advantages, it has a halal transaction ethics and clean from the elements of manipulation and fraud as well as upholding justice and blessing (Yuliana, Suhel, \& Bashir, 2017).

One of the growing Islamic financial instruments in Indonesia is sharia investment in the capital market. OJK explained that the Islamic capital market is a capital market activity that is not contrary to Islamic principles in the capital market. The concept of sharia stock trading is the concept of musharakah/shirkah activities, namely capital participation with profit sharing rights (Arshad \& Ismail, 2010; Meutia \& Adam, 2017). Thus, stocks do not contradicting with Islamic principles, because stocks are proof of equity participation from investors to companies, which then investors will get a profit sharing in the form of dividends (Al-Deehani, El- 
Sadi, \& Al-Deehani, 2015; Sherif, 2016). Buying and selling stocks in the Islamic capital market is a facility to bring together two interests, namely those who have excess funds (investors) and those who need funds (issuers/companies). Through the capital market, those who have excess funds would be able to invest and expecting to obtain legal compensation and in accordance with Islamic law, while issuers can utilize these funds for long-term funding of the company's operations.

Institution that conduct capital markets in Indonesia is the Indonesia stock exchange (IDX). The development of sharia stocks in the Indonesian capital market began with the issuance of the Jakarta Islamic Index (JII) in July 2000 which was limited to only 30 shares and the Indonesian Sharia Stock Index (ISSI) in May 2011. Both were issued by BAPEPAM-LK and Dewan Syariah Nasional-Majelis Ulama Indonesia (DSN-MUI). Indonesian sharia stock index is a sharia stocks consisting of all stocks registered on the Indonesia stock exchange and registered in list of sharia securities (DES). When it first issued, 214 stocks were registered in Indonesian sharia stock index. The development of the Indonesian sharia stock index in each period was quite significant. The Indonesia stock exchange data shows that until January 2019 there were 627 companies listed on sharia stock index (Bursa Efek Indonesia Syariah, 2019). The following figure is the progress of the Indonesian sharia stock index from May 2018 to March 2019.

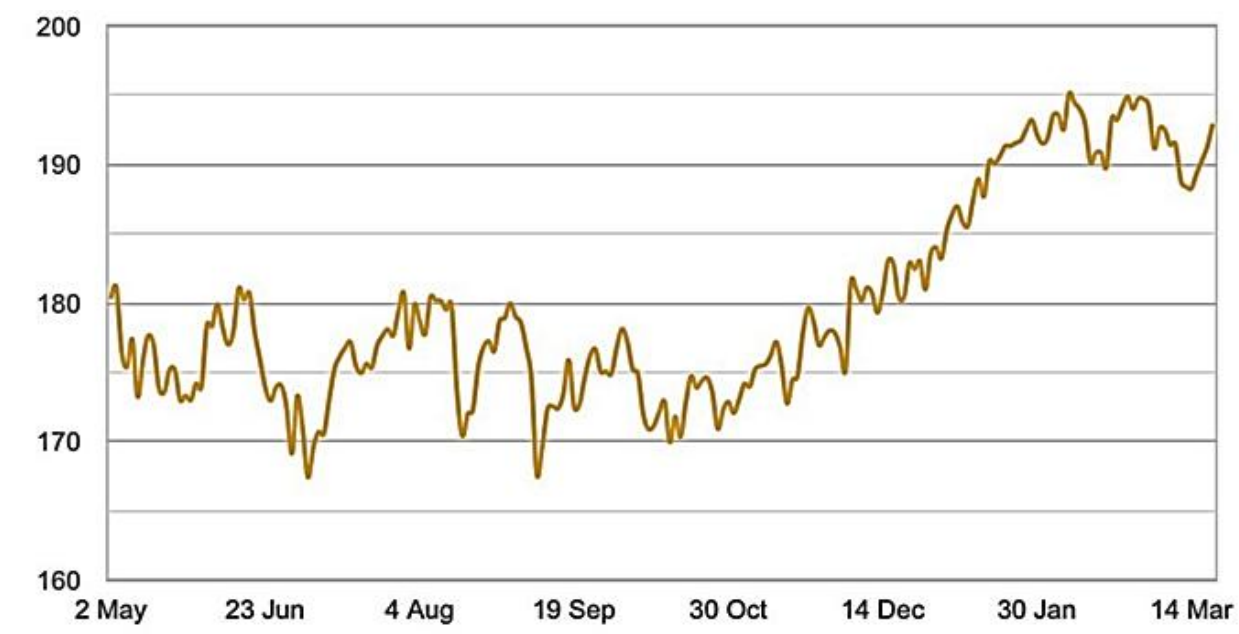

Figure 1. Progress of Indonesian sharia stock Index (May 2018-March 2019) Source: Bursa Efek Indonesia Syariah, 2019 (processed)

Figure 1 shows that the movement of sharia stock index every month shows a positive and stable trend, especially when entering October 2018 where it increased by around 175 points and continued to move significantly up to March 2019 increasing to around 195 points. Besides looking at the trend of movement and the value of stock sales, another factor considered by investors in investing in the capital market, especially the stock market is market capitalization. Large market capitalization is generally one of the attractions of investors in choosing stocks. Market capitalization is the market value of the outstanding shares of an issuer (Ang, 1997).

Market capitalization value is obtained by multiplying the number of shares outstanding by the stock market price. The size of the company on the stock market 
can be seen from its market capitalization, or in other words the market capitalization is the price of a company calculated from the total value of shares outstanding on the stock market. The following figure is development in the stock market capitalization on the Indonesia stock exchange over the past 6 years (Otoritas Jasa Keuangan, 2019).

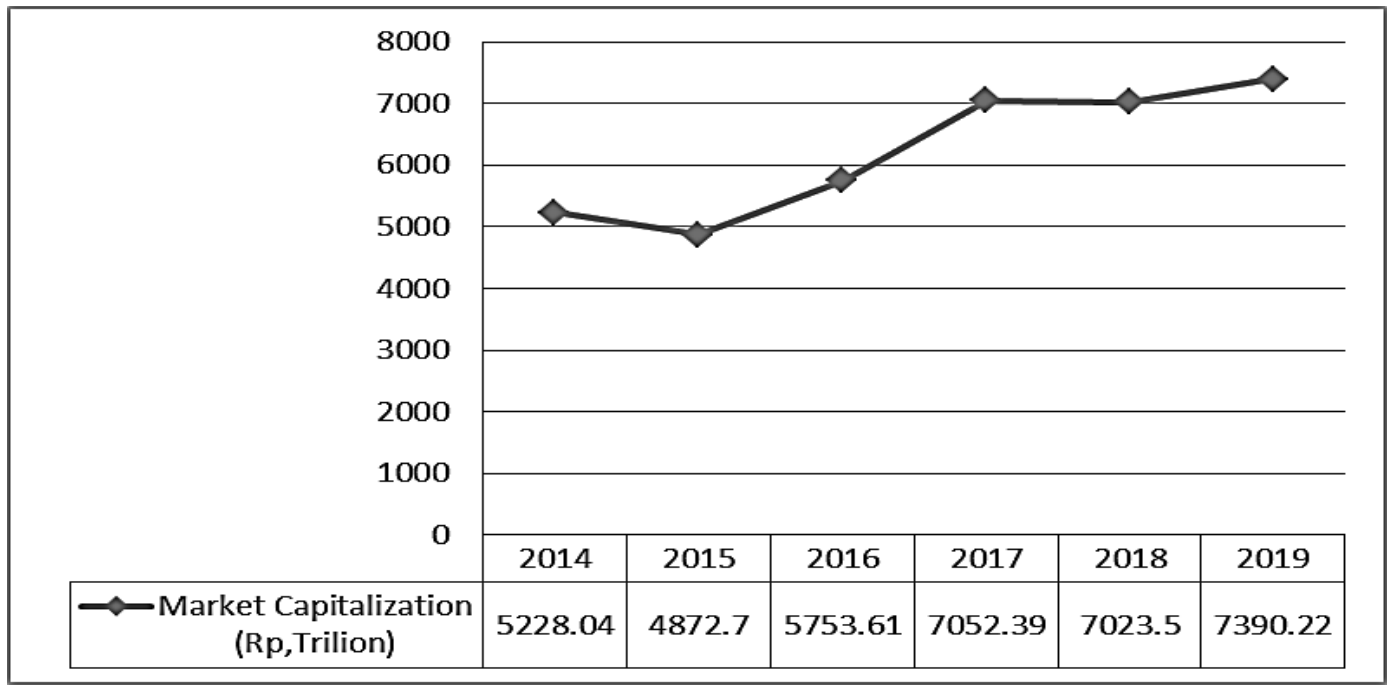

Figure 2. Development of Market Capitalization on the IDX in 2014-2019

Source: Otoritas Jasa Keuangan, 2019 (processed)

Figure 2 shows that the development of the stock market capitalization over the past 5 years shows an increasing trend, until March 2019 the value of its capitalization reached 7390.22 trillion. This indicates that the better and developing stock market in Indonesia and the more good companies listed on the Indonesia stock exchange stock market with large capitalization are targeted by investors to invest in the long term because of the amazing growth potential of the company, besides, good dividends and relatively low risk. Stocks that have a high market capitalization value are usually followed by a relatively high stock price, which will provide a high value of sales or profits as well, in the capital market commonly called return. The study conducted by Rifqiawan (2014) and Taslim \& Wijayanto (2016) states that market capitalization effects an increase in returns. Furthermore Garonfolo (2011) and Lukács (2002) also explained that by looking at stock prices itself is not enough to predict returns, it is necessary to look at market capitalization as well because stock prices are not always able to reflect the true value of a company.

High stock prices do not always conclude that the company is growing or has a high value. Market capitalization gives an idea of how much a company prices when sold on the market. This is used as a basis by investors to help in analysis how much the growth of a company. The greater the market capitalization of a stock, the longer the investor retains ownership of its stocks, because investors assume that large companies will tend to be more stable from the financial side, less risk, have good long-term prospects and high return expectations (Abdelbaki, 2013; and Gründl, Dong, \& Gal, 2016). 
Both Islamic stocks and stock market capitalization have a trend that tends to increase from period to period. This indicates that more companies have been listed in the Islamic stock index and more investors are participating in stock trading in the capital market and more and more companies are growing large. These two variables support each other in the performance of the Islamic capital market in supporting investment and economic growth in Indonesia. Therefore, the study aims to investigate the relationship between Islamic stock indexes and capital market capitalization.

\section{METHODS}

This study is quantitative descriptive using secondary data in the form of monthly time series data from May 2011 - May 2019 obtained from the official publications of Financial Services Authority (OJK) and Indonesia stock exchange (IDX). The data analysis are market capitalization (MC) and the Indonesian sharia stock index (ISSI) in units of trillion rupiah. The analysis technique in this study is the causality test using Granger causality. The causality test can indicate whether between variables have a two-way relationship or only one direction only. If it turns out that these variables have a two-way relationship, it means that these variables affect each other. In other words, there is a causal relationship between variables in the past to the present conditions. In the causality test the data used must be time series data because we need to see the effect of the past on the present condition (Widarjono, 2013). Furthermore, in the causality test there are no independent variables, all variables are dependent variables. In other words all variables are endogenous. The equation model used in the study is as follows:

$$
\begin{aligned}
& \Delta \mathrm{ISSI}_{\mathrm{t}}=\alpha_{1}+\sum_{\mathrm{l}=1}^{\mathrm{m}-\mathrm{i}} \beta_{1} \Delta \mathrm{ISSI}_{\mathrm{t}-1}+\sum_{\mathrm{l}=0}^{m-1} \gamma_{1} \Delta \mathrm{MC}_{\mathrm{t}-1}+\delta_{1} \mathrm{ECT}_{\mathrm{t}-1}+\varepsilon_{1 \mathrm{t}} \\
& \Delta \mathrm{MC}_{\mathrm{t}}=\alpha_{2}+\sum_{\mathrm{l}=1}^{\mathrm{m}-1} \beta_{2} \Delta \mathrm{MC}_{\mathrm{t}-1}+\sum_{\mathrm{l}=0}^{\mathrm{m}-\mathrm{i}} \gamma_{2} \Delta \mathrm{ISSI}_{\mathrm{t}-1}+\delta_{2} \mathrm{ECT}_{\mathrm{t}-1}+\varepsilon_{2 \mathrm{t}}
\end{aligned}
$$

Where: ISSI is Indonesia sharia stocks index; $\mathrm{MC}$ is market capitalization; the notation $\alpha_{1}, \alpha_{2}, \beta_{1}, \beta_{2}, \gamma_{1}, \gamma_{2}, \delta_{1}, \delta_{2}$ is coefficient; ECT is error correction term; $t$ - 1 is lag; e is errorterm.

Figure 3 shows the first step taken in the analysis is the stationary data test. When all variables are stationary, the next step is to determine the length of the Lag and then proceed with the co-integration test. Next, a vector auto-regression (VAR) is performed if the stationary test results show the data is stationary at the data level. But if the stationary test results show data is stationary at the difference level, then the vector error correction model (VECM) is conducted (Widarjono, 2013). Before proceeding to the last test, the causality test, it is better to conduct the impulse response and variance decomposition. This is to deepen the results of the analysis of causality tests. There are several stages of econometric statistical tests that must be passed in this study as follows: 


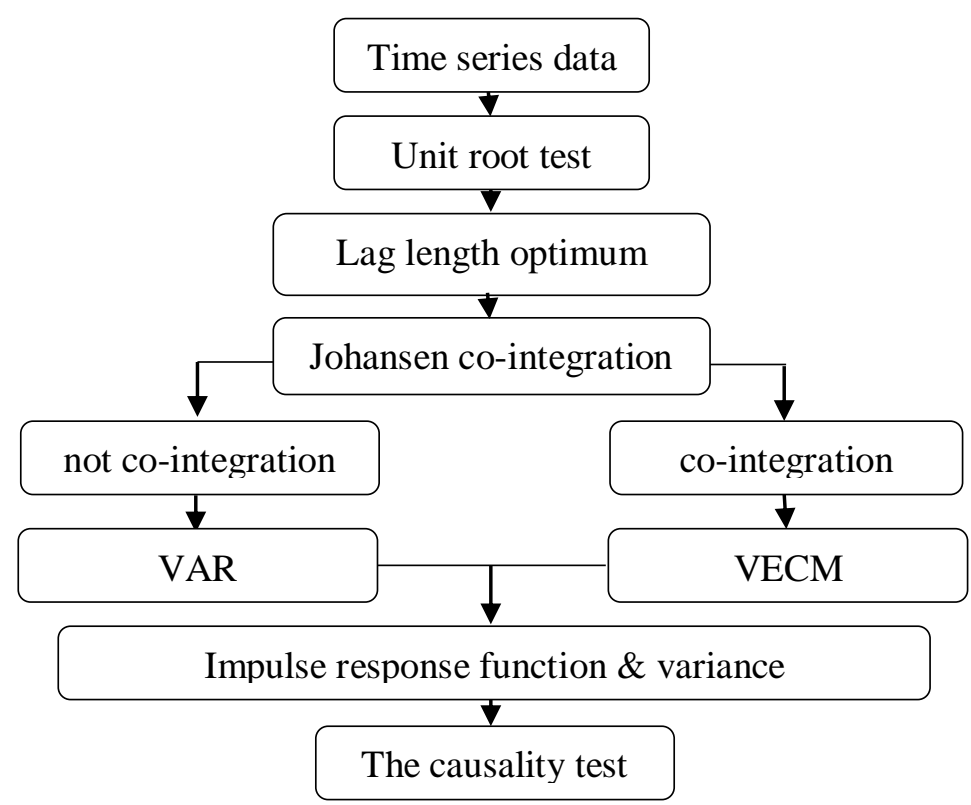

Figure 3. Stages of econometric statistical test

\section{RESULTS AND DISCUSSION}

\section{Unit root test}

Stationary data test can be performed using the Augmented Dickey-Fuller (ADF) unit root test at the level data, first difference, or second difference until a stationary data is obtained.

Table 1. Stationary test on the first difference

\begin{tabular}{lccc}
\hline Variables & ADF test & p-value & Summary \\
\hline ISSI & -9.264146 & 0,0000 & Stationary \\
MC & -8.378463 & 0.0000 & Stationary \\
\hline
\end{tabular}

Source: Authors calculations

From the Table 1 it can be seen that all variables have been stationary in the First Difference. This can be proven by the probability value is smaller than alpha 0.05 . Thus all data no longer contains unit root problems.

\section{Lag length criteria}

Determination of the lag length is important in the VAR or VECM model. It is needed to determine the length of the period of influence on other endogenous variables that can be seen from the Lag Criteria, namely Likelihood Ratio (LR), Final Prediction Error (FPE), Akaike Information Criterion (AIC), Schwarz Information Criterion (SC) and Hannan-Quinn Information Criterion (HQ). The results in the lag length test are determined by looking at the highest number of stars in each lag criteria test (Bahmani-Oskooee \& Brooks, 2003). 
Table 2. Lag Length Criteria

\begin{tabular}{ccccccc}
\hline Lag & $\log \mathbf{L}$ & LR & FPE & AIC & SC & HQ \\
\hline 1 & -1196.135 & 309.9662 & $1.85 \mathrm{e}+09 *$ & $27.01427^{*}$ & $27.18204^{*}$ & $27.08189^{*}$ \\
\hline
\end{tabular}

Source: Authors calculations

The lag length criteria test results showed that the lag criteria indicator gives the highest number of stars in lag 1.

\section{Johansen co-integration test}

The co-integration test aims to determine whether there will be a balance in the long run, that is to find out whether or not there is a similarity in the movement and stability relationships between the variables in the study (Johansen, 1988). The method used in this study is the co-integrating Johansen test.

Table 3. The Johansen co-integration test

\begin{tabular}{cccc}
\hline Trace Statistics & $\begin{array}{c}\mathbf{0 . 0 5} \\
\text { Critical Value }\end{array}$ & $\begin{array}{c}\text { Max-Eigen } \\
\text { Statistics }\end{array}$ & $\begin{array}{c}\mathbf{0 . 0 5} \\
\text { CriticalValue }\end{array}$ \\
\hline $31.89135^{* * *}$ & 15.49471 & $31.16081^{* * *}$ & 14.26460 \\
\hline
\end{tabular}

Source: Authors calculations

The result of co-integration test in Table 3, it is known that at the alpha level of 0.05 the value of Trace Statistics is greater than the Critical Value or 31.89135 > 15.49471. Likewise, the Max-Eigen Statistics value is greater than the critical value or $31.16081>14.26460$. This means that all the variables in the model have a longrun co-integration relationship. The results of the co-integration test indicate that between the movement of Indonesian sharia stock index and market capitalization have a stability/balance relationship and similarity of movement in the long-run. Because it is known that there is a co-integration relationship between variables, this study continues to the vector error correction model approach.

\section{The estimation of vector error correction model}

VECM is used in the VAR model if the time series data is not stationary at level data, but stationary at the level of differentiation and is co-integration. Based on the previous stationary test it has been found that the stationary variable is at first difference. In accordance with the provisions of the restricted VAR model, the test will then proceed to the VECM test.

Table 4. The VECM estimation result

\begin{tabular}{lcccc}
\hline Variables & $\mathbf{C}$ & ISSI $_{\mathbf{t}-\mathbf{1}}$ & MC $_{\mathrm{t}-\mathbf{1}}$ & Prob. \\
\hline ISSI $_{\mathrm{t}}$ & 8.663508 & -0.100641 & 0.353350 & 0.0185 \\
MC $_{\mathrm{t}}$ & 31.88991 & 0.046625 & 0.116795 & 0.5316 \\
\hline
\end{tabular}

Source: Authors calculations

The first model, the variable is statistically significant at level 5 percent. It means that the Indonesian sharia stock index trading value is influenced by the 
Indonesian sharia stock index trade value itself a month ago, and is influenced by the market capitalization on the stock exchange a month ago, where each increase of 1 trillion Indonesian sharia stock index trading values this month is due to the tendency of the increase in market capitalization last month by 0.35 trillion. The negative Indonesian sharia stock index value is suspected because investors are more dominant in seeing the magnitude of the market capitalization value instead of seeing the specific trading value of sharia stocks when trading on the Islamic capital market (Manasseh et al., 2018).

The second model, it turns out that market capitalization statistically insignificant at level 5 percent. It means that the market capitalization value has no effect on the Indonesian sharia stock index trading value. Means the size of the market capitalization value on the Indonesia stock exchange is only influenced by the value of market capitalization itself a month ago, where each 1 trillion increase in market capitalization value this month is due to last month's market capitalization value which tends to rise by 0.11 trillion.

\section{Impulse response function test}

Through impulse response we can track the shock of a variable for the next few periods and see how much the standard deviation changes due to the shock (Widarjono, 2013).

Table 5. Impulse response function tests

\begin{tabular}{cccc}
\hline \multicolumn{2}{c}{ Impulse response of ISSI to MC } & \multicolumn{2}{c}{ Impulse response of } \\
\hline Period & MC & Period & ISSI \\
\hline 1 & 0.000000 & 1 & 60.91063 \\
2 & 117.8179 & 2 & 86.07795 \\
3 & 88.16162 & 3 & 82.11303 \\
4 & 94.96707 & 4 & 82.46265 \\
5 & 89.75693 & 5 & 81.35482 \\
\hline
\end{tabular}

Source: Authors calculations

Both Table 5 and Figure 4 show the response of Indonesian sharia stock index to the shock from market capitalization. In the second month the market capitalization gave a fairly strong shock of 117.8179 standard deviations, then decreased in the 3rd month by 88.16162 and experienced a small increase in the 4th month of 94.96707 then followed to a stable return in the following months at a value of 89.75693. Meanwhile, the response of market capitalization to the shock of Indonesian sharia stock index. In the 2nd month, Indonesian sharia stock index gave a shock of 86.07795 standard deviations then started to stabilize in the 3rd month and the following months amounted to 81.35482 .

From the two impulse response tests above it can be said that the shock given by the market capitalization gives much greater effect than Indonesian sharia stock index. This means that if there is a change in the market capitalization value on the Indonesia stock exchange then the sharia stock index trading value will respond strongly in the second and third month before then heading to a new stable condition (Manasseh et al., 2018). 


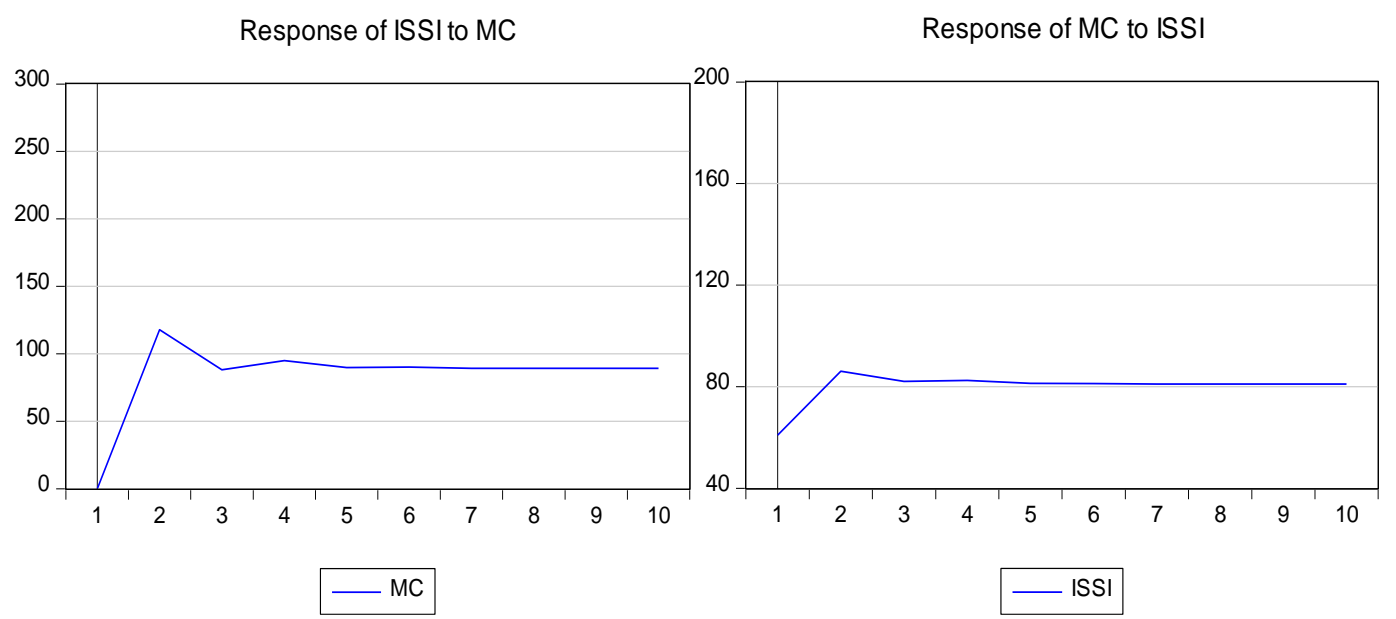

Figure 4. Impulse response function tests Source: Authors calculations

From the two impulse response tests above it can be said that the shock given by the market capitalization gives much greater effect than Indonesian sharia stock index. This means that if there is a change in the market capitalization value on the Indonesia stock exchange then the sharia stock index trading value will respond strongly in the second and third month before then heading to a new stable condition (Manasseh et al., 2018).

\section{Variance decomposition test}

The variance decomposition test illustrates the relative importance of each variable in the VAR system due to the shock and is useful for predicting the contribution of the variance percentage of each variable due to changes in certain variables in the VAR system (Widarjono, 2013).

Table 6. Variance decomposition test

\begin{tabular}{cccccc}
\hline & \multicolumn{2}{c}{ ISSI due to MC } & \multicolumn{3}{c}{ MC due to ISSI } \\
\hline Period & ISSI (\%) & MC (\%) & Period & ISSI $(\%)$ & MC $(\%)$ \\
\hline 1 & 100.0000 & 0.000000 & 1 & 11.31791 & 88.68209 \\
2 & 83.73372 & 16.26628 & 2 & 14.69872 & 85.30128 \\
3 & 78.11043 & 21.88957 & 3 & 14.74896 & 85.25104 \\
4 & 72.13909 & 27.86091 & 4 & 14.81609 & 85.18391 \\
5 & 67.72137 & 32.27863 & 5 & 14.76972 & 85.23028 \\
6 & 63.84761 & 36.15239 & 6 & 14.73661 & 85.26339 \\
7 & 60.55014 & 39.44986 & 7 & 14.70479 & 85.29521 \\
8 & 57.65728 & 42.34272 & 8 & 14.68048 & 85.31952 \\
9 & 55.11112 & 44.88888 & 9 & 14.66082 & 85.33918 \\
10 & 52.84767 & 47.15233 & 10 & 14.64509 & 85.35491 \\
\hline
\end{tabular}

Source: Authors calculations

Both Table 6 and Figure 5 show the shock from the market capitalization variable to Indonesian sharia stock index which continues to rise. The shock from 
the market capitalization contributed increasingly higher from period to period. In the second month period the Indonesian sharia stock index variant was explained by the variable itself by 83 percent, while the contribution of the market capitalization variable by 16 percent. So on in the 10 th month the contribution of market capitalization variables increased by 47 percent. This indicates that changes in market capitalization value contributed substantially and continuously to changes in the value of sharia stock trading.

Meanwhile, the shock from the Indonesian sharia stock index variable on market capitalization which tends to be flat. It can be seen that the shock of Indonesian sharia stock index only makes a small contribution from period to period. In the first month period the market capitalization variance was explained by the variable itself by 89 percent, and the contribution of the Indonesian sharia stock index variable by 11 percent. Until the second to ten-month, the contribution of the Indonesian sharia stock index variable was only 14 percent.

Variance Decomposition

Percent ISSI variance due to MC

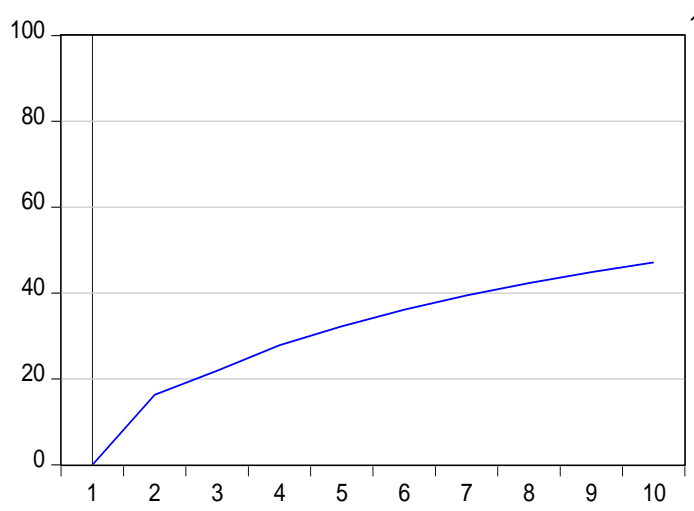

$-M C$
Variance Decomposition

Percent MC variance due to ISSI
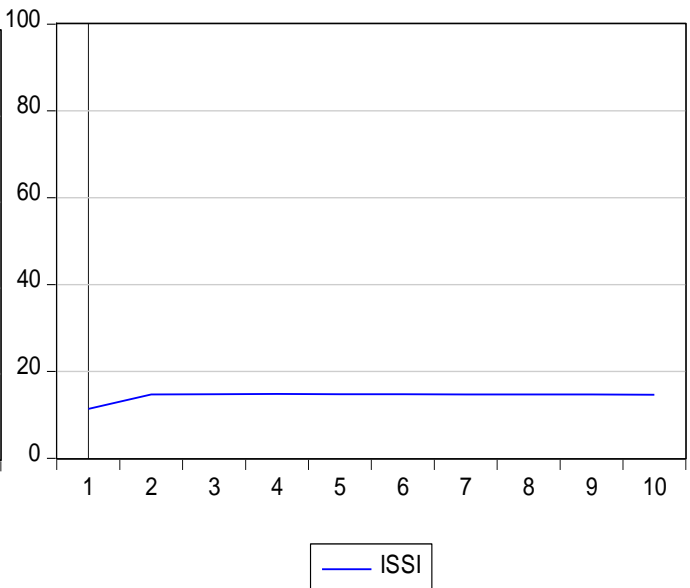

Figure 5. Variance decomposition test

Source: Authors calculations

This indicates that changes in the trading value of sharia shares tend not to contribute significantly to changes in the value of market capitalization on the Indonesia stock exchange. These findings in line and support the study result conducted by Robiyanto (2019) and Qoyum, Mardiya, \& Sakti (2017). From the two variance decomposition tests above it can be said that the value of market capitalization is relatively important and plays a role in changes in the value of sharia stock trading, while sharia stocks have relatively no role in changing the value of market capitalization.

\section{Granger causality test}

The virtue of the causality test is to indicate whether a variable has a twoway relationship or only one direction only by looking at the statistical significance of the probability value (Djalal, 2002). 
Table 9. The estimation of Granger causality model

\begin{tabular}{ccc}
\hline Granger Causality Test & Probability & Summary \\
\hline MC to ISSI & 0.0004 & causal \\
\hline ISSI to MC & 0.3515 & no causal \\
\hline
\end{tabular}

Source: Authors calculations

From the test results of the causality relationship between the market capitalization (MC) variables towards Indonesian sharia stock index (ISSI), it can be seen that there is a causality relationship between the market capitalization and Indonesian sharia stock index variables by looking at the probability value of 0.0004 which is smaller than alpha 0.05. This means that there is a causal relationship between the market capitalization variable to the Indonesian sharia stock index variable. While between the Indonesian sharia stock index variable on the market capitalization variable the probability value of 0.3515 is greater than alpha 0.05 . This means that there is no causal relationship between the Indonesian sharia stock index variable to the market capitalization variable. Thus, it can be said that there is only a one-way causality relationship between the market capitalization and Indonesian sharia stock index variables. Where the condition of market capitalization in the past affects the trading value of Indonesian sharia stock index in the present. While Indonesian sharia stock index trading value conditions in the past did not affect the current market capitalization value.

\section{CONCLUSION}

The conclusion of this empirical study i.e. (1) Based on the causality test that there is only a one-way causality relationship between the Indonesian sharia stock index and market capitalization variables. Where the condition of market capitalization in the past affects the trading value of Indonesian sharia stock index in the present. Whereas Indonesian sharia stock index trading value conditions in the past did not affect the current market capitalization value; (2) The VECM test results show that the current trading value of Indonesian sharia stock index is affected by market capitalization on the Indonesia stock exchange a month ago. In line with the results of the causality test which has only a one-way relationship, the rise or fall of the market capitalization value on the Indonesia stock exchange this month is not affected by the Indonesian sharia stock index trading value. Furthermore it seems that investors are suspected to be more dominant in seeing the magnitude of the market capitalization on Indonesia stock exchange instead of seeing the specific trading value of sharia stocks when trading on the Islamic capital market; (3) impulse response test indicated that the shock given by market capitalization gives much greater effect than Indonesian sharia stock index. This means that if there is a change in the market capitalization on Indonesia stock exchange then the sharia stock index trading value will respond strongly in the second and third month before then heading to a new stable condition; and (4) The variance decomposition test shows that the value of market capitalization is relatively important and plays a role in changes in the value of sharia stock trading, while sharia stocks have relatively no role in changing the value of market capitalization. 


\section{REFERENCES}

Abdelbaki, H. H. (2013). Causality Relationship between Macroeconomic Variables and Stock Market Development: Evidence from Bahrain. The International Journal of Business and Finance Research, 7(1), 69-84.

Al-Deehani, T. M., El-Sadi, H. M., \& Al-Deehani, M. T. (2015). Performance of Islamic banks and conventional banks before and during economic downturn. Investment Management and Financial Innovations, 12(2), 238-250.

Al-smadi, A. A. A., Almsafir, M. K., \& Mukthar, M. Bin. (2017). Global Financial Crisis of Islamic and Conventional Banking in Middle East - A Case Study in Turkey. International Journal of Economics and Finance, 9(8), 239-248. https://doi.org/10.5539/ijef.v9n8p239

Ang, R. (1997). The Intelligent Guide to Indonesian Capital Market. Jakarta: Mediasoft Indonesia.

Arshad, N. C., \& Ismail, A. G. (2010). Shariah parameters for Musharakah Contract: A comment. International Journal of Business and Social Science, 1(1), 145-162.

Bahmani-Oskooee, M., \& Brooks, T. J. (2003). A new criteria for selecting the optimum lags in Johansen's cointegration technique. Applied Economics, 35(8), 875-880. https://doi.org/10.1080/00036840210129419

Bursa Efek Indonesia Syariah. (2019). Statistik Indeks Saham Syariah. Jakarta.

Djalal, N. (2002). Penggunaan Teknik Ekonometri : Pendekatan Populer \& Praktis Dilengkapi Teknik Analisis \& Pengolahan Data dengan Menggunakan Paket Program SPSS. Jakarta: Raja Grafindo Persada.

Garonfolo, H. J. (2011). Macroeconomic Drivers of Stock Market Capitalization in Sub-Saharan Africa. Copenhagen Business School.

Gründl, H., Dong, M. I., \& Gal, J. (2016). The evolution of insurer portfolio investment strategies for long-term investing. OECD Journal: Financial Market Trends, 2016(1), 1-55.

Johansen, S. (1988). Statistical analysis of cointegration vectors. Journal of Economic Dynamics and Control, 12(2-3), 231-254. https://doi.org/10.1016/0165-1889(88)90041-3

Lukács, P. (2002). Stock Return Distribution and Market Capitalisation. Hungarian Statistical Review, 7(2002), 138-148.

Manasseh, C. O., Ogbuabor, J. E., Anumudu, C. N., Abada, F. C., Okolie, M. A., \& Okoro, O. E. (2018). The Causal Effect of Stock Market Development, Financial Sector Reforms and Economic Growth: The Application of Vector Autoregressive and Error Correction Model. International Journal of Economics and Financial Issues, 8(2), 357-369.

Meutia, I., \& Adam, M. (2017). Dissecting implementation musharakah in Islamic bank in Indonesia: a case study. Jurnal Akuntansi \& Auditing Indonesia, 21(1), 61-69.

Otoritas Jasa Keuangan. (2019). Statistik Saham Syariah. Jakarta.

Qoyum, A., Mardiya, M., \& Sakti, M. R. P. (2017). Indonesian Capital Market Efficiency: Islamic vis-a-vis Conventional. Shirkah: Journal of Economics and Business, 2(3), 283.

Rifqiawan, R. A. (2014). Pengaruh Profitabilitas dan Kapitalisasi Pasar terhadap Nilai Emiten Jakarta Islamic Index. Economica, VI(2), 21-36.

Robiyanto, R. (2019). Gold and capital market in Indonesia: A preview on strategy 
of hedging and diversification. Journal of International Studies, 12(2), 117128. https://doi.org/10.14254/2071-8330.2019/12-2/7

Sherif, M. (2016). Ethical Dow Jones indexes and investment performance: international evidence. Investment Management and Financial Innovations, 13(2), 216-225.

Taslim, A., \& Wijayanto, A. (2016). Pengaruh Frekuensi Perdagangan Saham, Volume Perdagangan Saham, Kapitalisasi Pasar dan Jumlah Hari Perdagangan terhadap Return Saham. Management Analysis Journal, 5(1), 1-6.

Widarjono, A. (2013). Ekonometrika: Pengantar dan Aplikasinya disertai Panduan Eviews. Yogyakarta: UPP STIM YKPN.

Yuliana, S., Suhel, \& Bashir, A. (2017). Comparative Analysis of Profit Sharing Financing Between Islamic Banks (BUS) and Islamic Rural Bank (BPRS) in Indonesia. International Journal of Economics and Financial Issues, 7(2), 266-270. 